\title{
Pengaruh Pemberian Salep Fraksi Etil Asetat Daun Jambu Biji (Psidium Guajava) Terhadap Luka Bakar Pada Mencit Putih (Mus Musculus L.)
}

\author{
Effect of Administration Of Ethyl Acetate Fraction Of Guava Leaves \\ (Psidium Guajava) On Burns In White Mice (Mus Musculus L.)
}

\author{
${ }^{1}$ Eko Pranoto, ${ }^{2}$ Dessy Dwi Risky Ayuningtias \\ 1,2Program Studi Farmasi, Fakultas Imu Kesehatan, Universitas Ibrahimy \\ ${ }^{1}$ Email : ekopranoto@ibrahimy.ac.id
}

\begin{abstract}
ABSTRAK
Jambu biji (Psidium guajava L.) merupakan salah satu bahan alam yang banyak tersebar. Daun jambu biji diteliti memiliki khasiat terhadap percepatan penyembuhan luka. Fraksi etil asetat ekstrak daun jambu biji terbukti memiliki aktivitas penyembuhan luka yang lebih baik dibandingkan fraksi air, fraksi etanol maupun n-heksan. Etil asetat sebagai pelarut semi polar mampu menarik senyawa yang sifatnya relative polar maupun non polar. Ekstrak yang potensial perlu untuk diformulasikan menjadi bentuk sediaan yang mudah untuk diaplikasikan, memberikan efek perlindungan dan menstabilkan senyawa aktif. Efek penyembuhan diujikan terhadap luka bakar pada mencit yang diberi perlakuan salep dengan konsentrasi ekstrak 5\%, 10\%, kontrol negatif dan kontrol positif. Pengujian dilakukan selama 14 hari dengan mengukur pengurangan diameter pada luka. Data hasil pengujian diolah menggunakan ANOVA dan menunjukkan adanya perbedaan yang berarti diantara kelompok pengujian (nilai $\mathrm{p}=0,003$ ). Pengolahan data menggunakan DUNCAN menunjukkan kelompok perlakuan yang diberi salep dengan konsentrasi $10 \%$ memberikan hasil yang setara dengan kelompok perlakuan kontrol positif.
\end{abstract}

Kata Kunci: Fraksi Etil Asetat, Daun Jambu Biji, Salep, Luka Bakar, Mencit

\section{ABSTRACT}

Guava (Psidium guajava L.) is one of the most widely distributed natural ingredients. Guava leaves have been investigated to have efficacy in accelerating wound healing. The ethyl acetate fraction of guava leaf extract was proven to have better wound healing activity than the water, ethanol and $n$ hexane fractions. Ethyl acetate as a semi-polar solvent is able to attract compounds that are relatively polar and non-polar. Potential extracts need to be formulated into dosage forms that are easy to apply, provide a protective effect and stabilize the active compound. The healing effect was tested on burns in mice that were treated with ointment with an extract concentration of 5\%, 10\%, negative control and positive control. The test was carried out for 14 days by measuring the reduction in the diameter of the wound. The test data were processed using ANOVA and showed a significant difference between the test groups ( $p$ value $=0.003$ ). Data processing using DUNCAN showed that the treatment group that was given the ointment with a concentration of $10 \%$ gave equivalent results to the positive control treatment group.

Keywords: Ethyl Acetate fraction, Guajava leaves, Ointment, Burns, Mice

\section{PENDAHULUAN}

Perawatan luka menjadi hal yang penting untuk mencegah berbagai komplikasi seperti pendarahan mencegah infeksi dan mendorong adanya percepatan penyembuhan. Salah satu perawatan luka yang kerap dilakukan oleh masyarakat secara luas ialah dengan pemberian obat luka baik 
secara topikal dan atau tanpa pemberian antibiotik untuk penanganan infeksi skunder. (Syamsuhidayat \& Jong, 1997).

Penanganan luka dengan pemberian obat secara topikal masih menjadi salah satu yang umum dilakukan oleh masyarakat. Sediaan topikal untuk pengobatan luka sudah banyak tersedia dan dengan mudah ditemui, beberapa obat luka yang tersedia di pasaran terdapat dalam bentuk sediaan yakni salep, gel, obat cair dan juga sediaan serupa patch dimana obat sudah menempel pada kain kasa atau plester pembalut luka. Namun dari banyaknya berbagai jenis sediaan untuk pengobatan luka, sediaan berbasis bahan alam yang beredar di pasaran masih sangat jarang atau bahkan sulit untuk ditemui. Ekplorasi terhadap berbagai tumbuhan maupun bahan alam masih sangat diperlukan untuk menemukan berbagai kandidat dan memperkaya pustaka untuk pengembangan obat baru berbasis bahan alam.

Jambu biji (Psidium guajava L.) merupakan salah satu bahan alam yang banyak ditemui dan tersebar merata di seluruh Indonesia. Daun jambu biji diketahui secara tradisional banyak digunakan sebagai obat diare, antibakteri dan astrigensia. Senyawasenyawa yang diketahui terkandung dalam daun jambu biji diantaranya alkaloid, flavonoid, tannin, quersetin serta flavonoid (Park et al., 2010). Penelitian terkait khasiat daun jambu biji yang lain adalah kolerasinya terhadap percepatan penyembuhan luka (Oktiarni et al. (2012). Ekstrak etanol daun jambu biji dengan konsentrasi $10 \%$ terbukti memberikan efek penyembuhan. Fraksi etil asetat kstrak daun jambu biji terbukti memiliki aktivitas penyembuhan luka yang lebih baik dibandingkan fraksi air, fraksi etanol maupun n-heksan. (Kumar, 2012). Etil asetat sebagai pelarut semi polar diduga mampu menarik senyawa yang sifatnya relatif polar maupun non polar.

Penelitian untuk dapat memperoleh sediaan yang aplikatif perlu dilakukan, sebagai tindak lanjut dari berbagai penelitian terkait khasiat daun jambu biji terhadap penyembuhan luka. Ekstrak yang potensial perlu untuk diformulasikan menjadi bentuk sediaan yang mudah untuk diaplikasikan. Formulasi sediaan yang tepat bukan hanya akan memudahkan dalam penggunaan, tapi juga akan membantu 
kandungan senyawa untuk terpenetrasi secara optimal, memberikan efek perlindungan dan menstabilkan senyawa. Pada penelitian ini fraksi etil asetat daun jambu biji akan diformulasikan menjadi sediaan salep. Keuntungan sediaan salep memiliki daya lekat yang baik, bersifat oklusif (Isrofah, dkk., 2015). Beberapa keuntungan sediaan salep tersebut dapat melindungi luka dari berbagai paparan luar yang dapat memicu terjadinya kerusakan skunder maupun infeksi.

\section{METODE PENELITIAN}

$\begin{array}{rrr}\text { Penelitian yang } & \text { dilakukan } \\ \text { merupakan jenis } & \text { penelitian }\end{array}$
eksperimental laboratorium. Penelitian yang dilakukan berfokus pada perubahan-perubahan yang teramati pada luka yang diberi sediaan salep hasil formulasi. Objek penelitian menggunakan Mencit Putih (Mus musculus L.) jantan yang berusia 2-3 bulan. Adapun bahan yang digunakan diantaranya daun jambu biji, etanol 96\%, n-heksan, etil asetat, vaselin album, Na-EDTA, $\mathrm{HCl}$, Serbuk Mg, $\mathrm{FeCl}_{3}$, adeps lanae, pereaksi dragendorf, kloroform, kertas label, pereaksi mayer, pereaksi wagner, aquadest, kertas saring, sarung tangan, kapas, aluminium foil. Sedangkan alat-alat yang digunakan diantaranya neraca analitik, pisau perajang, blender, ayakan, rotary evaporator, batang pengaduk, beaker glass, cawan porselen, mortar, stamper, Erlenmeyer, gelas ukur, pipet volum, pipet ukur, corong pisah, hot plate dan magnetic stirrer, oven, Loyang pengering, pipet tetes, kandang hewan, pisau cukur, kompor listrik, plat porselen, tabung reaksi, rak tabung reaksi, gunting, penggaris, kain lap.

\section{Pembuatan Simplisia}

Daun jambu biji yang diperoleh disortasi basah, kemudian dicuci bersih. Selanjutnya dikeringkan dalam suhu ruang. Setelah seluruh air yang menempel di permukaan hilang, daun jambu biji selanjutnya dirajang dan kembali dikeringkan menggunakan oven pada suhu $40^{\circ} \mathrm{C}$ selama 8 hari. Selanjutnya daun yang sudah kering dirajang kasar kemudian dihaluskan menggunakan blender. Serbuk daun kemudian diayak menggunakan ayakan nomor 40 dan ditimbang hingga diperoleh serbuk dengan berat 500 gram.

\section{Pembuatan Ekstrak dan Fraksinasi}

Ektrak dibuat dengan metode maserasi menggunakan etanol $70 \%$ sebagai pelarut. Satu bagian serbuk 
simplisia dimaserasi dengan satu bagian etanol. Maserasi silakukan kurang lebih 72 jam dengan mengganti pelarut tiap 12 jam. Ektrak yang diperoleh selanjutnya dipekatkan menggunakan rotary evaporator secara bertahap hingga diperoleh ekstrak kental.

Selanjutnya dilakukan fraksinasi pada ekstrak kental yang diperoleh. Seberat 20 gram ektrak kental dilarutkan dalam $100 \mathrm{ml}$ aquadest. Larutan dalam aquadest selanjutnya dilakukan fraksinasi bertingkat dengan menambahkan dengan n-heksan dengan perbadingan volume 1:1. Lakukan pemisahan n-heksan dan air berkali-kali hingga $n$-heksan menjadi bening. Pada fase ini fase air diambil kemudian difraksinasi kembali menggunakan etil asetat dengan perbandingan volume 1:

1. Fraksinasi air-etil asetat dilakukan berkali-kali hingga etil asetat berwarna bening. Pada tahap ini fase yang diambil adalah etil asetat. (Desiyana et $a l, 2016)$. Etil asetat yang diperoleh dari proses fraksinasi selanjutnya dipekatkan kembali menggunakan rotary evaporator sehingga diperoleh ekstrak kental.

\section{Penapisan Fitokimia}

Uji Alkaloid dilakukan dengan menambahkan 0,1 gram ekstrak dengan
$1 \mathrm{ml} \mathrm{HCl} 2 \mathrm{~N}$ dan $9 \mathrm{ml}$ aquadest. Selanjutnya disaring dan dipanaskan dengan penagas air kemudian ditambahkan pereaksi Meyer dan Dragendorf. (Gafur et al., 2013).

Uji Flavonoid dilakukan dengan melarutkan 0,1 gram ekstrak kental dalam $10 \mathrm{ml}$ etanol. Selanjutnya dibagi menjadi 4 tabung. Masing-masing tabung ditambahkan $\mathrm{H}_{2} \mathrm{SO}_{4}$ pekat, $\mathrm{NaOH}$, serbuk $\mathrm{Mg}-\mathrm{HCl}$ pekat dan tabung keempat sebagai kontrol. Jika pada ketiga tabung yang ditambahkan pereaksi terdapat perubahan warna maka ekstrak positif mengandung flavonoid. (Gafur et al., 2013).

Uji omoge dilakukan dengn menimbang seberat 0,1 gram simplisia dengan $10 \mathrm{Ml}$ aquadest. Kemudian disaring. Filtrate diambil sebanyak $2 \mathrm{Ml}$ kemudian ditambahakan 15 Ml aquadest. Selanjutnya ditambahkan 2 tetes $\mathrm{FeCl}_{3}$ 1\%. Hasil positif ditunjukkan dengan adanya perubahan warna biru kehitaman atau hijau kehitaman.

Uji Saponin dilakukan dengan melarutkan 0,1 gram ekstrak kental dengan $15 \mathrm{Ml}$ air panas. Selanjutnya dipanaskan selama 5 menit, kemudian disaring. Filtrate yang dipeoleh dikocok selama 30 detik. Jika terdapat busa yang 
tidak hilang selama 10 detik, maka positif mengandung saponin. (Gafur et al., 2013).

Uji steroid, 0,1 gram ekstrak ditambahkan dengan $10 \mathrm{Ml}$ etanol. Bagi ke dalam 2 tabung reaksi. Pada salah satu tabung tambahkan 5 tetes $\mathrm{H} 2 \mathrm{SO} 4$ pekat dan 2 tetes asam asetat anhidrat. Amati perubahan yang terjadi pada tabung yang ditambahkan reagen dengan tabung lain yang menjadi pembanding. Jika terjadi perubahan warna hijau atau kebiruan maka ekstrak positif mengandung steroid. (Gafur et al., 2013).

\section{Pembuatan Salep}

Salep yang akan dibuat pada penelitian ini terdiri dari konsentrasi $0 \%$ (basis salep), konsentrasi 5\% dan 10\%. Basis yang digunakan adalah adeps lanae dan vaselin album. Adapun konsentrasi tiap bahan salep ditampilkan pada omog 1.1.

Proses pembuatan salep dilakukan pertama-tama dengan mencampurkan adeps lanae dengan vaselin album hingga omogeny. Tambahkan metil paraben, propil paraben dan dan dinatrium EDTA lalu aduk kembali hingga homogen. Selanjutnya ekstrak yang telah ditimbang dimasukkan pada campuran basis dilakukan pencampuran secara konstan hingga campuran omogeny. Selanjutnya sediaan yang telah dibuat diuji organoleptiknya, nilai $\mathrm{pH}$, daya sebar dan homogenitasnya.

Tabel 1.1 Rancangan Formula Salep Daun Jambu Biji

\begin{tabular}{llll}
\hline \multicolumn{1}{c}{ Bahan } & \multicolumn{3}{c}{ Konsentrasi } \\
& \multicolumn{1}{c}{ A } & \multicolumn{1}{c}{ B } & \multicolumn{1}{c}{ C } \\
\hline Ekstrak & $0(\%)$ & $5(\%)$ & $10(\%)$ \\
Dinatrium EDTA & 0,1 & 0,1 & 0,1 \\
Metil Paraben & 0,1 & 0,1 & 0,1 \\
Propil Paraben & 0,05 & 0,05 & 0,05 \\
Gliserin & 1,5 & 1,5 & 1,5 \\
Propilen glikol & 1 & 1 & 1 \\
Adeps Lanae & 12 & 12 & 12 \\
Vaselin Allbum & 85,25 & 80,25 & 75,25 \\
$\quad$ Total & 100 & 100 & 100 \\
\hline
\end{tabular}

\section{Penyiapan Hewan Coba dan}

\section{Pembuatan Luka Bakar}

Hewan uji disiapkan dalam empat kelompok yang terdiri dari kelompok kontrol negatif, kelompok kontrol positif dan kelompok perlakuan. Setiap kelompok terdiri dari 5 hewan uji. Kelompok kontrol positif adalah kelompok yang mendapat pengobatan menggunakan salep yang digunakan untuk luka bakar yang biasa diperoleh di apotek. Sednagkan kontrol negatif merupakan kelompok yang akan diberikan basis salep saja.

Mencit yang sudah disiapkan dicukur bagian punggungnya hingga nampak kulit. Selanjutnya mencit dibius menggunakan kloroform untuk mempermudah dalam 
pengkondisiannya. Dibuat luka bakar pada mencit di masing-masing kelompok dengan diameter kurang lebih $1 \mathrm{~cm}$. masing-masing kelompok terdiri dari 5 ekor mencit.

Pengobatan luka bakar terhadap mencit dilakukan dengan memberikan perlakuan terhadap setiap kelomok selama 14 hari. Pengobatan dilakukan sebanyak 2 kali dalam sehari. Selanjutnya progress luka yang diamati berupa pengurangan diameter luka yang terbuka atau tampilan luka yang sudah mulai tertutup. Selanjutnya selisih lebar luka sebelum dan

\section{HASIL DAN PEMBAHASAN}

\section{Ekstraksi dan Fraksinasi}

Hasil maserasi diperoleh total $1500 \mathrm{ml}$ maserat yang selanjutnya ekstrak dikentalkan sehingga diperoleh 8,12 gram ekstrak kental. Fraksinasi bertingkat dilakukan untuk memperoleh ekstrak dalam pelarut etil asetat. Hasil proses fraksinasi bertingkat diperoleh sekitar 1,1 gram ektrak kental. Hasil fraksinasi ditampilkan pada gambar 1.1

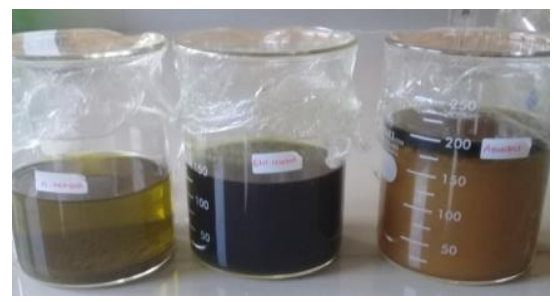

Gambar 1.1 hasil fraksinasi ekstrak daun jambu biji
Kurang lebih $1500 \mathrm{ml}$ maserat yang diekstraksi menggunakan pelarut etanol, setelah proses fraksinasi hanya diperoleh diperoleh sekitar $450 \mathrm{ml}$ yang terpisah dalam pelarut etil asetat. Perbedaan jumlah rendemen ini disebabkan karena proses fraksinasi bertingkat yang dilakukan sebelumnya yakni fraksinasi awal antara air dan nheksan. Pada tahap ini, n-heksan yang merupakan pelarut non polar akan menarik senyawa-senyawa yang bersifat non polar dan yang memiliki sifat kepolaran rendah. Sehingga pada fase air hanya akan tersisa senyawa-senyawa yang bersifat polar dan semi polar. Selanjutnya pada tahap fraksinasi kedua antara air dan etil asetat, fase etil asetat akan mengikat komponen-komponen semi polar, sedangkan komponen dengan kepolaran yang tinggi akan cenderung tertinggal pada fase air.

Etil asetat akan membentuk ikatan hidrogen dengan senyawa-senyawa pada rendemen. Ikatan hidrogen ini terbentuk karena adanya gugus metoksi yang terdapat pada struktur kimia etil asetat. Ikatan hidrogen yang terbentuk cenderung lemah, hal ini menyebabkan jumlah senyawa yang dapat ditarik oleh etil asetat lebih sedikit dibanding etanol (Romadanu dkk, 2014). 
Skrining Senyawa Metabolit Skunder

Uji alkaloid yang dilakukan pada fraksi etil asetat dengan penambahan reagen tidak menunjukkan adanya kekeruhan atau endaan yang terbentuk. Hal ini menunjukkan bahwa pengujian menunjukkan hasil yang negatif. Alkaloid merupakan senyawa yang umumnya bersifat semipolar namun cenderung terikat kuat pada pelarut non polar dibanding pelarut polar (Iffah dkk, 2018) sehingga senyawa ini terikat pada n-heksan sebagai pelarut non polar pada proses fraksinasi pertama.

Uji saponin pada fraksi etil asetat juga menunjukkan hasil yang negatif. Pengocokan yang dilakukan pada sampel tidak menghasilkan busa. Saponin merupakan senyawa non polar yang akan terikat dengan pelarut non polar yakni n-heksan pada tahap fraksinasi pertama.

Uji flavonoid, tanin dan steroid yang dilakukan menunjukkan hasil positif. Jenis flavonoid dapat terikat pada pelarut polar dan jenis yang lain dapat terikat pada pelarut non polar. Sehingga flavonoid dapat ditarik oleh berbagai jenis pelarut sesuai dengan kepolarannya. Adanya kandungan flavonoid, tannin dan steroid ini sejalan dengan penelitian yang dilakukan oleh Fernandes dkk sebelumnya.

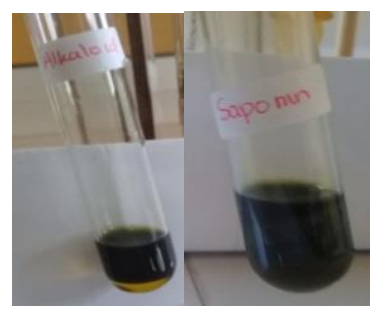

Gambar 1.2 Pengujian alkaloid dan saponin menunjukkan hasil negatif

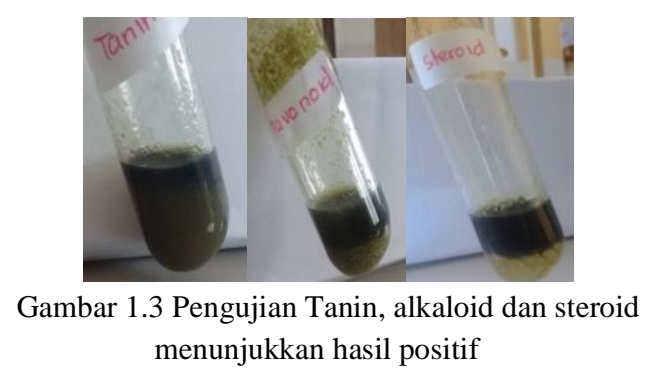

Pembuatan Salep Salep Fraksi Etil

\section{Asetat Ektrak Daun Jambu Biji}

Salep dibuat dalam 3 formula yakni salep tanpa kandungan ekstrak atau basis, serta salep dengan kandungan ektrak 5\% dan $10 \%$. Masing-masing formula dibuat dalam jumlah yang cukup yaitu sebanyak 10 gram.

Pada penelitian ini digunakan adeps lanae dan vaselin album dipilih sebagai basis dalam sediaan obat luka kaeena dapat memberikan daya rekat dan bersifat oklusif sehingga memberi perlindungan pada luka. Propilen glikol berperan sebagai humektan dan juga untuk mencegah penguapan. Gliserin digunakan sebagai emolien dan 
humektan dimana keduanya juga memiliki efek sebagai agen antiinflamasi, sehingga sangat sesuai untuk dijadikan basis dalam obat luka. Selain itu, gliserin juga digunakan untuk menstabilkan propilen glikol dan mempertahankan konsistensi salep tetap lembut.

Gambar 1.4 Hasil Pembuatan Salep Fraksi Etil Asetat Daun Jambu Biji

Masing-masing formula yang telah dibuat diamati secara organoleptis dan pengujian daya sebar pada ketiga formula salep secara ringkas ditampilkan pada tabel 1.2

Tabel 1.2. Hasil Pengamatan Organoleptis Salep

\begin{tabular}{|c|c|c|c|c|}
\hline \multirow[b]{2}{*}{ Gel } & \multicolumn{4}{|c|}{ Jenis Evaluasi } \\
\hline & Warna & Bau & $\begin{array}{l}\text { Homogeni } \\
\operatorname{tas}\end{array}$ & $\begin{array}{l}\text { Daya } \\
\text { Sebar }\end{array}$ \\
\hline Basis & $\begin{array}{l}\text { Putih } \\
\text { Keruh }\end{array}$ & $\begin{array}{l}\text { Khas vaselin } \\
\text { album }\end{array}$ & Homogen & 2,13 \\
\hline $\begin{array}{l}\text { Salep } \\
5 \%\end{array}$ & Hijau & $\begin{array}{l}\text { Khas asam } \\
\text { asetat }\end{array}$ & Homogen & 2,21 \\
\hline $\begin{array}{l}\text { Salep } \\
10 \%\end{array}$ & Hijau & $\begin{array}{c}\text { Khas asam } \\
\text { asetat }\end{array}$ & Homogen & 2,24 \\
\hline
\end{tabular}

Berdasarkan hasil pengujian daya sebar menunjukkan formula dengan kandungan ekstrak paling banyak yakni $10 \%$ memiliki daya sebar yang paling besar. Hal ini salah disebabkan adanya komponen yang beragam dengan jumlah yang semakin nesar akan mempengaruhi konsistensi sediaan.
Sehingga dalam hal ini jumlah ekstrak yang semakin banyak akan menyebabkan sifat salep lebih encer dan lembut sehingga lebih memudahkan penyebaran salep.

Pengaruh Pemberian Salep Fraksi Etil Asetat Terhadap Penyembuhan Luka Bakar

Pengaruh pemberian salep fraksi etil asetat terhadap penyembuhan luka pada penelitian ini berfokus pada empat kelompok yakni kelompok kontrol positif, kelompok kontrol negatif dan dua kelompok perlakuan. Setiap kelompok diberi perlakuan dan diaplikasikan salep dua kali sehari berturut-turut selama 14 hari. Kemajuan pengobatan dan proses penyembuhan dengan mengamati dan menganalisis kondisi luka pada tiap kelompok yakni dengaan melihat kondisi kropeng pada luka dan pengurangan diameter luka yang diukur pada hari ke 2 dan hari ke 14. Kondisi kropeng pada luka untuk tiap kelompok ditampilkan sebagai berikut 


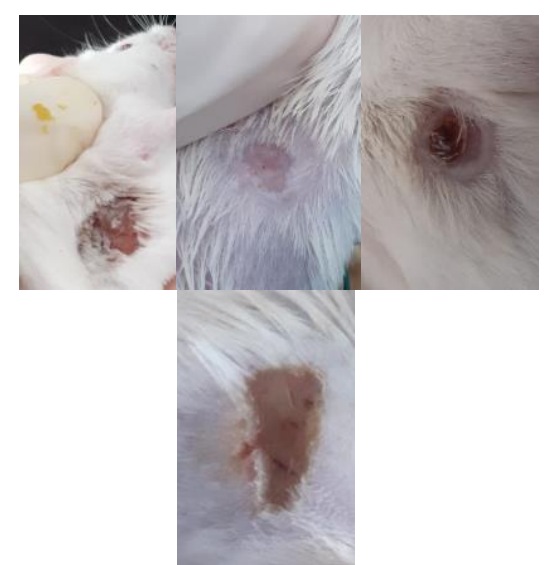

Gambar 1.5 tampilan kondisi luka pada hari ke 14: kontrol negatif (A), kontrol positif (B), salep 5\% (C), salep 10\% (D)

Pengamatan dilakukan dengan mengukur diameter luka setelah seluruh kelompok diberi perlakuan. Pengukuran ini dilakukan tanpa melihat fase atau tahapan penyembhan yang terjadi pada luka. Seluruh hewan uji diberi tanda dan diukur diameter luka pada hari pertama, hari ke tujuh setelah perlakuan dan hari ke 14. Selisih diameter luka ditampilkan pada tabel berikut.

Tabel 1.3 Selisih diameter luka setelah perlakuan

\begin{tabular}{llllll}
\hline $\begin{array}{c}\text { Kelompok } \\
\text { Uji }\end{array}$ & $\begin{array}{c}\text { Pengurangan } \\
\text { Diameter luka setelah } \\
\text { hari 14(cm) }\end{array}$ & $\begin{array}{c}\text { Rata- } \\
\text { rata }\end{array}$ \\
& I & II & III & IV & \\
\hline Kontrol & 0,2 & 0,1 & 0,0 & 0,1 & 0,150 \\
Negatif & & & & & \\
Kontrol & 0,3 & 0,2 & 0,3 & 0,2 & 0,225 \\
Positif & & & & & \\
salep 5\% & 0,2 & 0,1 & 0,2 & 0,1 & 0,175 \\
Salep 10\% & 0,2 & 0,2 & 0,2 & 0,3 & 0,2 \\
\hline
\end{tabular}

Data pengurangan diameter luka selanjutnya data diuji normalitas dan homogenitasnya. Uji normalitas menggunakan Kolmogorov diperoleh nilai $\mathrm{p}$-value sebesar 0,316 nilai ini lebih besar dibandingkan nilai $\alpha$ yang menyatakan data terdistribusi normal. Uji dilanjutkan untuk melihat homogenitas data dengan melakukan uji Levene dan diperoleh p-value sebesar 0,588 . Nilai p-value yang lebih besar dibanding nilai $\alpha$ menunjukkan bahwa data yang diuji homogen.

Pengolahan dilakukan untuk melihat signifikansi pengaruh pemberian salep dengan persen ekstrak yang berbeda terhadap pengurangan diameter luka pada mencit. Data diolah menggunakanuji ANOVA dan diperoleh nilai $\mathrm{p}=0,003(\mathrm{p}<0,05)$ yang menunjukkan adanya pengaruh yang signifikan dengan adanya pemberian salep terhadap pengurangan diameter luka. Pengujian dilanjutkan dengan uji Duncan untuk mengetahui perlakuan yang memberikan nilai signifikan. Hasil pengolahan data ditunjukkan pada table berikut

\begin{tabular}{lcccr}
\multicolumn{5}{c}{ Tabel 1.4 Hasil Pengolahan Data Menggunakan Duncan } \\
\hline Konsentrasi & \multicolumn{5}{c}{ Subset for alpha = 0.05 } \\
Salep & $\mathrm{N}$ & 1 & 2 & 3 \\
\hline Kontrol Negatif & 4 & .0750 & \\
Salep5\% & 4 & .1500 & .1500 & \\
Salep10\% & 4 & & .2250 & .2250 \\
Kontrol Positif & 4 & & & .2500 \\
Sig. & & .073 & .073 & .525 \\
\hline
\end{tabular}

Hasil Duncan menunjukkan pengurangan diameter luka secara signifikan terjadi pada kelompok kontrol negatif jika dibanding dengan 
kelompok perlakuan salep $10 \%$ dan kelompok kontrol positif. Sedangkan kelompok kontrol negatif tidak memberikan pengaruh yang signifikan jika dibandingkan dengan kelompok yang diberi salep dengan konsentrasi ekstrak 10\% dan kelompok kontrol positif. Hasil uji juga menunjukkan bahwa konsentrasi salep yang memberikan hasil setara dengan kontrol positif adalah salep dengan kandungan ekstrak $10 \%$.

Senyawa aktif yang terkandung didalam fraksi etil asetat daun jambu biji yang memberikan efek penyembuhan luka diperkirakan adalah golongan senyawa flavonoid dan tanin. Adanya flavonoid dan tannin dalam fraksi etil asetat ekstrak daun jambu biji berperan sebagai antibakteri yang mencegah pembusukan jaringan selama proses penyembuhan. Flavonoid utama yang terkandung pada jambu biji adalah kuersetin dimana kadar kuersetin pada jambu bijibanyak terdapat pada bagian daun (Jayakumari et al, 2012)

\section{SIMPULAN DAN SARAN}

Salep fraksi etil asetat daun jambu biji dengan konsentrasi 10\% memiliki efek penyembuhan yang hampir setara dengan efek penyembuhan menggunakan salep komersil yang digunakan dalam penyembuhan luka bakar. Adanya kandungan flavonoid dalam ekstrak daun jambu biji memiliki efek sebagai antibakteri yang mencegah adanya pembusukan jaringan selama proses penyembuhan. Bahan-bahan dalam formula slep diantaranya gliserin dan propilen glikol memberikan efek pelembaban yang mendukung penyembuhan luka.

\section{Pengembangan Ilmu}

Pengukuran secara kuantitatif terhadap flavonoid dan tannin pada ektrak etanol dan fraksi etil asetat sehingga dapat diketahui kandungan zat yang diduga berperan dalam penyembuhan luka.

\section{DAFTAR PUSTAKA}

Allen, LV. 2002. The Art, Science, aand Technology of Pharmaceutical Compounding. American Pharmaceutical Association, Washington DC.

Amirlak, B. (2015, July 18). Skin Anatomy: Overview, Epidermis, Dermis. Diambil kembali dari Medscape :http://emedicine medscape.com/ article/1294744- overview

Aponno, J. V., Paulina V. Y. Yamlean, dan Hamidah S. Supriati. 2014. Uji Efektivitas Sediaan Gel Ekstrak Etanol Daun Jambu Biji (Psidium guajava Linn.) Terhadap Penyembuhan Luka 
Yang Terinfeksi Bakteri Staphylococcus aureus pada Kelinci (Orytolagus cuniculus). Pharmacon. 3 (3). Issn 23022493.

Aziz, Z. and Djamil, R., 2013, Isolasi dan Identifikasi Senyawa Flavonoid dalam Fraksi nbutanol dari Ekstrak Etanol Daun Jambu Biji (Psidium guajava L.), Prosiding Seminar Nasional LUSTRUM $\mathrm{X}$ Fakultas Farmasi Universitas Pancasila.

Cahyono B. 2010. Sukses Budidaya Jambu Biji di Pekarangan dan Perkebunan. Yogyakarta (ID): Lily Publisher.

Desiyana, L., Husni, MA and Zhafira, S. 2016. Uji Evektivitas Sediaan Gel Fraksi Etil Asetat Daun Jambu Biji (Psidium guajava Linn.) Terhadap penyembuhan luka terbuka pada mencit (Mus muculus). Jurnal Natura.

Fernandes, K P S., Sandra Kalil Bussadori, Marcia Martins Marques, Nisa Sumie, Yamashita Wadt, Erna Bach, Manoela Dominingues Martins. 2010. Healing and cytotoxic effects of Psidium guajava (Myrtaceae) leaf extracts. Braz J Oral Sci. 9(4):449-454.

Gafur, M. A., L. Isa, \& N. Balangi. 2013. Isolasi dan Identifikasi senyawa flavonoid dari daun $\mathbf{J}$ amblang (Syzygium Cumini). Skripsi Program Dtudi Kimia. Fakultas MIPA, Universitas Negeri Gorontalo, Gorontalo
Giretzlehner M, Dirnberger J, Owen R, Haller HL, Lumenta DB, and Kamolz LP, 2013. The Determination of Total Burn Surface Area: How Much Difference Burns. 39(6): 11071113.

Iffah, A. A., Rani, C. dan Samawi, M. F. 2018. Skrining Metabolit Sekunder pada Sirip Ekor Hiu Carcharhinus melanopterus. Departemen Ilmu Kelautan, Fakultas Ilmu Kelautan dan Perikanan, Universitas Hasanuddin

Isrofah, Sagiran, afandi, M. 2015. Efektivitas Salep Ekstrak Daun Binahong (Andredera Cordifolia (Ten) Steenis) Terhadap Proses Penyembuhan Luka Bakar Derajat 2 Termal Pada Tikus Putih (Rattus Novergicus). Universitas Muhammadiyah Yogyakarta.

Jayakumari, S., J. Anbu, V. Ravichandiran, A. Anjana, G.M. Siva Kumar, M. Singh. 2012. Antiulcerogenic and Free Radical Scavenging Activity of Flavonoid Fraction of Psidium guajava Linn Leaves. Intl. J. Pharm. and pharmaceutical sci. Vol 4 (1). Issn 0975-1491.

Kumar, A. 2012. Importance for Life 'Psidium guajava', a review article. Intl. J. R. Pharm. Biomed. Sci. 3(1) Issn 22293701

Menteri Kesehatan. 2009. Farmakope Herbal Indonesia. Edisi pertama. Keputusan Menteri Kesehatan Republik Indonesia 
Nomor

261/MENKES/SK/IV/2009.

Oktiarni, Dwita. 2012."Pemanfaatan Ekstrak Kulit Buah Naga Merah (Hylocerus polyrhhizus sp.) Sebagai Pewarna Dan Pengawet Alami Mie Basah". Jurnal Gradien, Vol.8.No.2:819-824.

Park et al. Protection of Burn-Induced Skin Injuries by the Flavonoid Kaempferol. BMB Reports. 2010; 43(1): 46-51.

Romadanu, Rahmawati, S. H., Lestari, S. W. 2014. Pengujian Aktivitas Antioksidan Ektrak Bunga Lotus (Nelumbo nucifera). Program Studi Teknologi Hasil Perikanan. Fakultas Pertanian. Universitas Sriwijaya Indralaya Ogan Ilir

Sheridan, R.L., 2012. Burns: A Practical Approach To Immediate Treatment and Long Term Care. London: Manson Publishing.

Smith, B. J. dan S. Mangkoewidjojo. 1988. Pemeliharaan, Pembiakan dan Penggunaan Hewan Percobaan di Daerah Tropis Indonesia. University Press, Jakarta

Syamsuhidayat, dan Jong, W., 1997. Buku Ajar Ilmu Bedah. Edisi Revisi. Jakarta: EGC.

Tjitrosoepmo, G. 2007. Taksonomi Tumbuhan (Spermatophyta). Gadjah Mada University Press, Yogyakarta. 16. BPOM RI. 2006. Monografi Ekstrak
Tumbuhan Obat Indonesia. Volume 1. BPOM RI, Jakarta.

Trubus. 2012. Herbal Indonesia Berkhasiat. Vol.10. Trubus, Depok. Issn 0216-7638. 18. Rowe, R.C., Paul J Sheskey, dan Marian E Quinn. 2003. Handbook of Pharmaceutical Excipient. 4th ed. Pharmaceutical Press, Washington, DC. 